JAVIER CIFUENTES-FAURA, Ph.D. candidate ${ }^{1}$

(Corresponding author)

E-mail: javier.cifuentes@um.es

URSULA FAURA-MARTÍNEZ, Ph.D. ${ }^{1}$

E-mail: faura@um.es

${ }^{1}$ University of Murcia

Faculty of Economics and Business

Campus de Espinardo, 30100 Murcia, Spain
Science in Traffic and Transport Original Scientific Paper

Submitted: 15 Jan. 2021

Accepted: 21 Apr. 2021

DOI: $10.7307 /$ ptt.v33i4.3790

\title{
TWENTY YEARS OF AIRPORT EFFICIENCY - A BIBLIOMETRIC ANALYSIS
}

\begin{abstract}
This paper analyses the scientific study on airport efficiency in the WoS (Web of Science) database for the period 2000-2019. Productivity indicators have been obtained by author, years, journals, and institutions, and an analysis of visibility, impact, and scientific collaboration through co-citations was performed. The areas of greatest application are transport, engineering, and economics. This study reveals the existence of three research lines, one on airport safety and management, another on technical efficiency using mainly the DEA method, and the third associated with airport regularization issues. An important issue which is increasingly taken into account in efficiency studies is related to environmental aspects. In the ranking of journals publishing on airport efficiency, ordered by number of articles indexed in WoS, Journal of Air Transport Management is the one with the highest number of cited articles and publications, whereas Sustainability stands out as the first non-specific journal on transport. The University of Lisbon and the University of British Columbia are the ones that deal most with airport efficiency.
\end{abstract}

\section{KEYWORDS}

bibliometric evaluation; efficiency; airports; Web of Science; co-citations.

\section{INTRODUCTION}

The airport sector has grown considerably in recent years due to the creation of new air routes and the intensification of the existing ones. Tourism is a growing trend worldwide, and airports are becoming increasingly necessary. The number of passengers is growing every year and airports must be prepared to manage passenger traffic and carry out their functions efficiently. Airports have to be able to meet the new challenges and demands of their customers and stakeholders. The aim is to improve connectivity between destinations and offer a quality service, avoiding problems of congestion and delays. Furthermore, there is no doubt about the economic impact that the presence of an airport has both at a local and national level [1-3] and the need to evaluate this impact according to the characteristics of each airport $[4,5]$. In addition, one of the problems currently faced is the need to reduce pollutant gas emissions and use alternative energy sources to fossil fuels. These are just some of the many issues related to air transport that can be discussed by researchers [6].

The increase in the number of scientific publications on this subject is proof of the importance that the airport sector has acquired in recent years. According to the Web of Science (WoS), a total of 74 articles on airport efficiency were published in 2019, compared to 25 in 2010. Likewise, before 2000, publications in this field were in the minority, which shows the lack of interest a few years ago.

In this work, an analysis of the behaviour of scientific production on airport efficiency in the WoS database will be carried out. The bibliometric analysis is based on the study of the publications, with indicators on the author's productivity (number of works signed), productivity per year (works carried out in the year), productivity per journal, and per institution.

The treatment given to the study of airport efficiency by various authors and institutions will be analysed. Specifically, the total volume, growth path, and distribution of published documents and research methods will be known. We will also find out which journals, authors, and research papers have had the greatest influence and which topics have been most frequently studied in recent years in the literature on airport efficiency. In addition, maps will be created to visualise bibliometric 
networks and several indicators will be used to deepen the analysis of publications as well as citations and co-citations.

The results reveal that the knowledge of airport efficiency is a subject whose relevance has acquired greater interest over the years and whose results have had a positive impact on the scientific field. Along the lines of research, questions related to security aspects, structure, management, and regulation of airports stand out, using advances in parametric and non-parametric statistical techniques related to efficiency in the last decade. There is also greater concern for taking into account aspects of sustainability such as the reduction of carbon emissions and the improvement of environmental management.

The identification of the lines of research and their interconnections, based on the information in the WoS database, is essential for understanding the structure and development of knowledge in this important field. In this way, scientific evaluation becomes of special interest as a support for decision-making and the design of scientific policies that are consistent with the current situation.

\section{METHODOLOGY}

The aim of this work is to present the situation of documentary research related to the efficiency of airports ("efficiency" understood in a broad sense, encompassing both economic and operational aspects). To this end, a bibliometric analysis is carried out with the aim of identifying, organising, and analysing the main elements within a specific field. In addition, the evolution of interest in the topic is presented, showing the most relevant authors, countries, journals, and key words.

Web of Science (WoS) and Scopus are the world's leading databases for bibliographic references and citations of publications. They contain articles that have been published in prestigious journals and are assumed to be of high quality, have a high impact factor, and therefore positively affect the researcher's curriculum [7-9], regardless of the quality of the published content [10]. Recent studies show that Scopus covers a larger number of non-English publications [11, 12], but the WoS hosts a larger number of older publications [13, 14]. From the WoS database, the famous "impact factor" of journals is compiled: the Journal Citation Report (JCR) in its Science Citation Index-Expanded version, available on the Web of Knowledge portal. This index is what determines the importance of the
WoS database [15]. Wang and Waltman [16] state that the WoS indexes journals better than Scopus. Codina et al. [17] consider that the coverage of Scopus is superior to that of WoS in the field of social sciences and humanities publications, which is not the case in which our research is situated. In view of the above, the WoS database has been selected to analyse the scientific literature related to the topic of airport efficiency.

The choice of search fields is made taking into account the title, summary, and keyword fields as these have the greatest descriptive value within each record and are more representative according to the literature review carried out [18].

The terms "Efficienc*" and "Airport" were used together as search terms in the title, abstract or keywords of the Web of Science Core Collection and only the results corresponding to document type "Article" were selected. A database of these research papers was created. The following variables were recorded for each journal: title, publisher, country, language of the journal, geographical origin of the publication, number of papers, number of citations received, and abstract.

Bearing in mind that the first year in which there are records on these concepts in the WoS database is 1947 and that almost 50 years have to pass before at least a dozen papers a year can be counted, the evolution over the last twenty years (period 20002019 ) is analysed. This period of time has been analysed because it is a prolific time period in terms of publications, and because in recent years, tourism has increased considerably, increasing the interest in learning more about airport efficiency.

Direct citation analysis is used to identify prominent authors and publications, calculating the number of times it has been cited by other authors or WoS publications. Knowing the productivity of the authors will allow us to know the most fruitful researchers, according to the WoS database, in the area of airport efficiency. In this way, anyone interested in this field can follow the updates of the works of these authors to find out about any progress they make. Through the co-citation of authors (two authors are cited at the same time by a third) the affinity between them can be determined [19]. The greater the number of documents cited that have the same pair of documents in their references, the greater the affinity [20]. The thematic, semantic, conceptual, and cognitive structure of this area of research is also studied by examining co-words. To 
carry out the analysis and visualization of the co-citation and co-word networks, the data are imported into the bibliometric program VOSviewer, which generates clusters, grouping the nodes so that the distance between them reflects their similarity [21-24].

\section{ANALYSIS OF THE RESULTS}

Based on the search conducted on airport efficiency over the last 20 years, a total of 1,715 references were recorded, of which 1,081 correspond to articles, 686 are part of "Proceedings Paper", 21 are "Reviews", and 33 are "Book chapters". The rest were "abstract", "editorial", and "others".

Among all these references, there are many in which the subject dealt with is not really directly related to the efficiency of airports (for example, in some of them the industrial clusters carried out in areas close to an airport are analysed; the contribution of the infrastructures of any type of transport to regional convergence is evaluated; a mechanism for detecting multiple objects based on colour textures is designed and implemented using a morphological gradient approach as elements that play an important role in the intelligent video surveillance system implemented in different areas such as airports,...). These are just samples of different works that include both terms in the subject and are not part of this research. For this reason, all the articles have been reviewed one by one to find out which ones are included in our database, leaving 671 articles. In an initial analysis, it can be seen that the documents are mainly written in English (98.3\%), 1\% in Spanish, and the rest in Chinese, Portuguese, and Polish.

\subsection{Analysis of publications}

The longitudinal analysis suggests that the knowledge base on airport efficiency has grown fairly continuously over the period 2000-2019 (Figure 1). $80 \%$ of the papers have been published since 2010 and just over 52\% in the last 5 years, showing that research on airport efficiency is increasingly attractive to academics.

Although contributions to the literature on the efficiency analysis come from almost 100 different countries, about $25 \%$ of the output comes from China as well as the United States, and another 25\% from England, Spain, Portugal, and Canada with a similar share of authors from each country. The rest come from a wide variety of countries: Australia, Germany, Italy, Netherlands, Brazil, Japan, etc.

With these 671 papers, more than 7,000 pages of academic information related to airport efficiency have been published in WoS-indexed journals, with an average of 13.8 pages per paper.

According to the downloaded database, the total number of authors who have signed these papers is 1,834 , some of them having published several times. However, this information is wrong, as it represents the same author under several different names. For example, it considers the authors CP Barros, Carlos Barros, Carlos P. Barros, Carlos Pestana Barros, and Carlos Pfstana Barros. According to the information downloaded, CP Barros is the author of three publications, Carlos P. Barros and Carlos Barros have both published two papers, Carlos Pestana Barros is the author of 14 publications, and Carlos Pfstana Barros has published one paper. Reviewing each of these works, it has been verified that they are all made by the same author, Carlos Pestana Barros, who therefore has 22 publications.

Once all the errors regarding the names of the authors have been resolved, 1,395 authors remained, compared with 1,834 that would have been obtained if the results had been analysed directly with the WoS application. Carlos Pestana Barros, Tae Hoon Oum, Anming Zhang, and Ming-Miin Yu stand out as the largest producers, that is, with 10 or more articles. A total of 232 authors are moderately productive, presenting from 2 to 8 publications. The

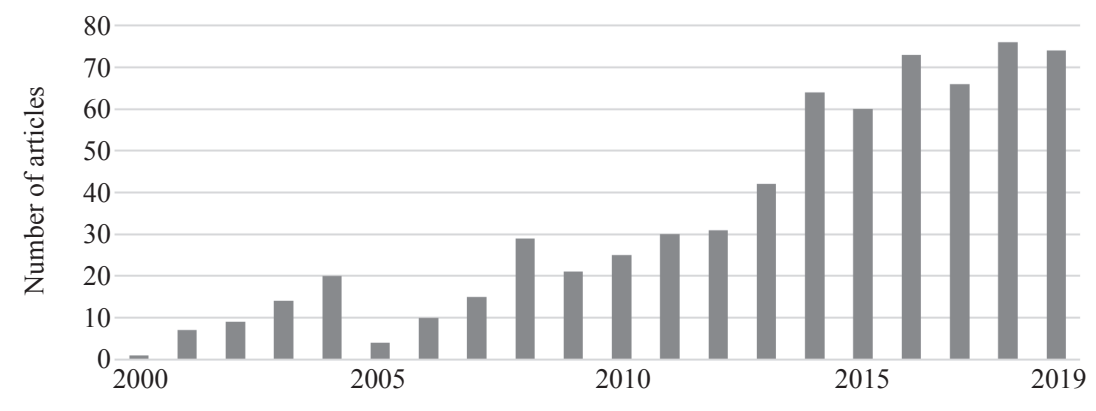

Figure 1-Growth path in airport efficiency research (WoS, 2010-2019) 
rest have only one publication. Table 1 presents the most productive and significant authors in the analysed period of time.

The journal that stands out with the largest number of publications (Table 2) is undoubtedly the Journal of Air Transport Management whose line of work is focused on addressing the main economic, management, and policy issues related to the

Table 1 - Authors with more than 5 articles on airport efficiency (WoS, 2000-2019)

\begin{tabular}{||l|c||}
\hline \multicolumn{1}{|c|}{ Author } & No. of articles \\
\hline \hline Barros, Carlos Pestana & 22 \\
\hline Oum, Tae Hoon & 12 \\
\hline Zhang, Anming & 13 \\
\hline Yu, Ming-Miin & 10 \\
\hline Martin Juan Carlos & 8 \\
\hline Fung, Michael Ka Yiu & 7 \\
\hline Chen, Jun & 6 \\
\hline Chow, Clement Kong Wing & 6 \\
\hline Gillen, David & 6 \\
\hline Hansen, Mark & 6 \\
\hline Marques, Rui Cunha & 6 \\
\hline Martini, Gianmaria & 6 \\
\hline Voltes-Dorta, Augusto & 6 \\
\hline Yoshida, Yuichiro & 6 \\
\hline
\end{tabular}

air transport industry in quartile 2 (Q2) of the year 2019. Most journals belong to the first or second quartile. Journals in the top positions have the term "transport" or some other aviation-related term in their title, so they are highly focused journals. Not all journals have the same annual publication frequency and this, therefore, could influence the number of articles. Considering the number of issues per year, the Journal of Air Transport Management continues to be the journal with the highest number of publications per issue.

The articles were published in 262 different journals, indicating that the interest in the study of airport efficiency is not exclusive to a few "specialist journals". This is supported by a wide range of topics covered by these journals, including Management, Environmental Sciences, or Mathematics, among others. Specifically, in the 10 most widely used areas of research (Table 3), there are both works published in the journals of the disciplines under study and works by authors from outside the discipline that are published in the journals of their own speciality.

Since the names of institutions in the Web of Science database may vary because some authors indicate their main institution as affiliation and others list their department or faculty, the terms have been standardised to measure productivity by

Table 2 - Journals publishing on airport efficiency ordered by number of articles indexed in WoS, 2000-2019

\begin{tabular}{||l|c|c|c||}
\hline \multicolumn{1}{|c|}{ Journal title $^{\mathrm{a}}$} & $\mathrm{N}^{\mathrm{o}}$ art. & Area & WoS quartile \\
\hline \hline Journal of Air Transport Management (8) & 114 & TR & Q2 \\
\hline Transportation Research Part E-Logistics and Transportation Review (12) & 32 & TR, ENG, OPR & Q1 \\
\hline Transportation Research Part A-Policy and Practice (12) & 28 & TR, ST & Q2 \\
\hline Transportation Research Part C-Emerging Technologies (12) & 22 & TR,ST & Q1 \\
\hline Transport Policy (12) & 19 & ECO, TR & Q1 \\
\hline Journal of Transport Economics and Policy (3) & 12 & ECO, TR & Q1 \\
\hline Transportation Research Part B-Methodological (12) & 11 & ST, ENG & Q1 \\
\hline IEEE Transactions on Intelligent Transportation Systems (12) & 11 & TR, ENG & Q1 \\
\hline Journal of Transport Geography (8) & 10 & ECO, GEO, TR & Q1 \\
\hline Sustainability (continuous publication model) & 10 & ENV, GST & Q2 \\
\hline Transportation Planning and Technology (8) & 10 & TR, ST & Q4 \\
\hline Transportation Research Record (12) & 10 & TR, ST, ENG & Q4 \\
\hline International Journal of Transport Economics (3) & 9 & ECO, TR & Q3 \\
\hline Mathematical Problems in Engineering (continuous publication model) & 9 & ENG, MTH & Q3 \\
\hline Transportation Research Part D-Transport and Environment (12) & 7 & TR & Q2 \\
\hline
\end{tabular}

${ }^{a}$ Number of issues/year in parenthesis

$E C O=$ Economy, ENV= Environmental, GST= Green \& Sustainable Science \& Technology, ENG= Engineering; GEO= Geography, MTH= Mathematics, $O P R=$ Operations Management and Research, ST= Science and Technology, TR= Transport 
Table 3 - List of the 10 research areas most involved in research on airport efficiency (WoS, 2000-2019)

\begin{tabular}{||l|c||}
\hline \multicolumn{1}{|c|}{ Research areas } & Total \\
\hline \hline Transportation & 336 \\
\hline Business \& Economics & 217 \\
\hline Engineering & 206 \\
\hline Operations Research \& Management Science & 88 \\
\hline Environmental Sciences \& Ecology & 41 \\
\hline Computer Science & 36 \\
\hline Science \& Technology & 23 \\
\hline Mathematics & 17 \\
\hline Energy \& Fuels & 14 \\
\hline Social Sciences & 14 \\
\hline
\end{tabular}

institution. The authors belong to almost 800 different institutions. The Technical University of Lisbon and the University of British Columbia have the largest number of researchers in this area. Most of the institutions are public, although some are private (Massachusetts Institute of Technology). It should be noted that there are some institutions that specialise in the field of aviation, such as the Nanjing University of Aeronautics and Astronautics.

\subsection{Citation analysis}

The selected articles have been cited 11,769 times, of which 11,285 in WoS-indexed journals. In addition, the number of different documents in which they are cited exceeds 4,000. The 10 most frequently cited authors are listed in Table 4. Tae Hoon Oum from the University of British Columbia has 685 citations in WoS of the 12 articles in the sample analysed. He is followed by Carlos Pestana Barros with 317 citations, but generated from a greater number of articles (22). There are authors who have many citations from only one or two articles, such as Xing Cai and Wei Li.

Table 5 shows the top 10 most frequently cited articles in order of average number of citations per year in the WoS database. The one with the most citations is Li and Cai's 2004 paper [25], published in Physical Review. They study China's airport network, determining that the efficiency of sub-clusters (a sub-cluster is composed of a hub, the central node, and its neighbourhood consisting of whoever has flights with the hub) of the airport network of China increases with the increase of the density of connectivity.

In the work of Sarkis [26] and Sarkis and Talluri [27], the operational efficiency of 44 U.S. airports in the period 1990-1994 was studied, based on various resources, such as airport operational costs, number of airport employees, gates and runways, and taking into account the results they have in terms of operational revenue, passenger flow, commercial and general aviation movement, and total cargo transportation. They identify clusters with inherently similar airports. They conclude that, in most airports, the organizational resources and capacities are well utilised or are reaching their limitations. Furthermore, the hub airports are more efficient for each year. Martin and Roman [28] analyse the efficiency of Spanish airports to study their overall performance. Pels et al. [29] show that, in European airports, airline inefficiency is passed on to airports, and that privately operated and corporatised airports are more efficient on average. Gillen and Lall [30] also connect the efficiency of airlines, in this case low-cost carriers, to the efficiency of airports. Oum, Yan, and $\mathrm{Yu}$ [31] and Oum, Adler and Yu [32] study

Table 4 - Top 10 most cited authors in WoS, 2000-2019

\begin{tabular}{||l|l|c|c|c|c||}
\hline \multicolumn{1}{|c|}{ Author } & \multicolumn{1}{c|}{ Institution } & Country & N $^{\text {art. }}$ & Citations & Citations per art. \\
\hline \hline Oum, Tae Hoon & University of British Columbia & Canada & 12 & 685 & 57.1 \\
\hline Barros, Carlos Pestana & Technical University of Lisbon & Portugal & 22 & 617 & 28.0 \\
\hline Yu, Chunyan & Embry Riddle Aeronautical University & USA & 5 & 447 & 89.4 \\
\hline Yu, Ming-Miin & National Taiwan University & Taiwan & 10 & 350 & 35.0 \\
\hline Gillen, David & University of British Columbia & Canada & 6 & 349 & 58.2 \\
\hline Zhang, Anming & University of British Columbia & Canada & 13 & 338 & 26.0 \\
\hline Cai, Xing & Nanjing University & China & 2 & 328 & 164.0 \\
\hline Li, Wei & Central China University & China & 1 & 305 & 305.0 \\
\hline Sarkis, J & Clark University & USA & 2 & 301 & 150.5 \\
\hline Martin, Juan Carlos & University of Las Palmas de Gran Canaria & Spain & 8 & 300 & 37.5 \\
\hline
\end{tabular}

Note: The citations are based on the citations in other documents contained in WoS on 1 December 2020 
Table 5 - List of the 10 most cited articles on airport efficiency (WoS, 2000-2019)

\begin{tabular}{|l|c|c|c|c||}
\hline \multicolumn{1}{|c|}{ Article title } & \multicolumn{2}{c|}{ Citations } & \multicolumn{2}{c||}{ Average per year } \\
\cline { 2 - 5 } & WoS & $\begin{array}{c}\text { Google } \\
\text { Scholar }\end{array}$ & WoS & $\begin{array}{c}\text { Google } \\
\text { Scholar }\end{array}$ \\
\hline \hline Statistical analysis of airport network of China [25] & 305 & 590 & 19.1 & 36.9 \\
\hline $\begin{array}{l}\text { An analysis of the operational efficiency of major airports in the } \\
\text { United States [26] }\end{array}$ & 178 & 471 & 8.9 & 23.6 \\
\hline $\begin{array}{l}\text { An application of DEA to measure the efficiency of Spanish air- } \\
\text { ports prior to privatization [28] }\end{array}$ & 154 & 361 & 8.1 & 19.0 \\
\hline $\begin{array}{l}\text { Inefficiencies and scale economies of European airport operations } \\
\text { [29] }\end{array}$ & 151 & 350 & 8.9 & 20.6 \\
\hline $\begin{array}{l}\text { Ownership forms matter for airport efficiency: A stochastic frontier } \\
\text { investigation of worldwide airports [31] }\end{array}$ & 138 & 300 & 11.5 & 25.0 \\
\hline $\begin{array}{l}\text { Privatization, corporatization, ownership forms and their effects on } \\
\text { the performance of the world's major airports [32] }\end{array}$ & 136 & 333 & 9.7 & 23.8 \\
\hline $\begin{array}{l}\text { Measuring the economic efficiency of airports: A Simar-Wilson } \\
\text { methodology analysis [34] }\end{array}$ & 124 & 244 & 10.3 & 20.3 \\
\hline Performance based clustering for benchmarking of US airports [27] & 123 & 308 & 7.7 & 19.3 \\
\hline $\begin{array}{l}\text { Competitive advantage of low-cost carriers: some implications for } \\
\text { airports [30] }\end{array}$ & 119 & 312 & 7.4 & 19.5 \\
\hline $\begin{array}{l}\text { Performance evaluation of Italian airports: A data envelopment } \\
\text { analysis [33] }\end{array}$ & 119 & 274 & 9.2 & 21.1 \\
\hline
\end{tabular}

a The citations are based on the citations in other documents contained in WoS on 1 December 2020.

${ }^{b}$ Google Scholar citations are based on citations from other sources contained in Google Scholar as of 1 December 2020, after removal of duplication.

the effects of ownership forms on the airports' cost efficiency for the major Asia, Australian-New Zealand, European, and North American airports. The results show that airports with government majority ownership and those owned by multi-level governance are significantly less efficient (productive efficiency and profitability) than airports with a private majority ownership, and that privatization of one or more airports in cities with multiple airports would improve the efficiency of all airports. An estimation of the determinants of the efficiency of Italian airports in terms of their total productivity is made by Barros and Dieke [33, 34]. They show that the greater the workload unit (a measure that aggregates passengers and freight in the following form: $1 \mathrm{WLU}=1$ passenger $=100 \mathrm{~kg}$ of freight) the greater the airport efficiency; that large airport authorities are more efficient than small airport authorities, and that airports that are partially private contribute to efficiency.

Most of the papers focus on the analysis of technical efficiency in airport activities using parametric and non-parametric methods. Among the parametric ones, we can highlight econometric procedures such as Stochastic Frontier Analysis (SFA) to estimate the production function. Among the non-parametric ones, they use Data Envelopment Analysis (DEA) or Total Factor Productivity (TFP). Furthermore, it has been proven that almost a third of the 671 works use the DEA method with some of its variations (Malmquist Index, Boostraping, DEA Window...). These works have been published in the last decade, showing that the application of this methodology in practice is almost immediate in the field of study that we are analysing as progress is made in its theoretical development.

In the field of research, it is essential to disseminate the results obtained to the scientific community in order to measure the impact of such research, either by the number of citations or by the mentions that a specific publication has had. Given the great popularity and use of Google Scholar among Internet users, in which searches are carried out in different sources (repositories, databases, or journal portals), disciplines, and publication formats available on the Internet, an analysis of the citations offered by Google Scholar of the most cited articles in WoS has also been carried out. In this way, it is possible to have a reference of the real projection that a work has had in the academic world. The number 
Table 6 - Ranking of journals with airport efficiency articles with most citations in WoS (WoS, 2000-2019)

\begin{tabular}{||l|c|c|c||}
\hline \multicolumn{1}{|c|}{ Journal title $^{\mathrm{a}}$} & $\begin{array}{c}\mathrm{N}^{\mathrm{o}} \\
\text { citations }\end{array}$ & $\begin{array}{c}\mathrm{N}^{\mathrm{o}} \\
\text { Articles }\end{array}$ & $\begin{array}{c}\text { Average number } \\
\text { of citations per } \\
\text { article }\end{array}$ \\
\hline \hline Journal of Air Transport Management (8) & 2697 & 114 & 23.7 \\
\hline $\begin{array}{l}\text { Transportation Research Part E-Logistics and Transportation Review } \\
(12)\end{array}$ & 1173 & 32 & 36.7 \\
\hline Transportation Research Part A-Policy and Practice (12) & 549 & 28 & 19.6 \\
\hline Transport Policy (12) & 307 & 19 & 16.2 \\
\hline Physical Review E (12) & 305 & 1 & 305.0 \\
\hline Transportation Research Part C-Emerging Technologies (12) & 268 & 22 & 12.2 \\
\hline Omega-International Journal of Management Science (8) & 251 & 6 & 41.8 \\
\hline Journal of Urban Economics (6) & 244 & 5 & 48.8 \\
\hline Journal of Transport Economics and Policy (3) & 208 & 12 & 17.3 \\
\hline Journal of Operations Management (8) & 178 & 1 & 178.0 \\
\hline Transportation Research Part B-Methodological (12) & 166 & 11 & 15.1 \\
\hline \hline
\end{tabular}

${ }^{a}$ Number of issues/year in the parentheses

of citations in Google Scholar is practically double, which demonstrates the great impact of the research in this field although it may also be due to the fact that citation data are strongly influenced by the coverage of the database used [35]. Liu and Cai's work continues to have the highest number of citations on Google Scholar with 36.9 citations per year.

If we focus on the analysis by journals (Table 6), those with the most citations are the Journal of Air Transport Management and Transportation Research Part E-Logistics and Transportation Review, but if we consider the average number of citations per article, then Physical Review E and Journal of Operations Management stand out.

Table 7 shows the 10 journals with the most citations of the articles in the sample studied. If we compare Tables 6 and 7, the first three positions are occupied by the same journals, which indicates that these are possibly the most specialised journals in this research topic.

In addition to knowing who publishes and where, it is very interesting to know which topics are mostly addressed when studying the efficiency of airports and which authors specialise in them. For this purpose, an analysis of co-citations of authors and words has been carried out. The co-citation map has been created from the file obtained from WoS using the Vosviewer programme developed by Nees Jan van Eck and Ludo Waltman (version 1.6.11, http://
Table 7 - Ranking of the WoS journals that most cite the selected articles

\begin{tabular}{||l|c||}
\hline \multicolumn{1}{|c|}{ Journal title } & $\begin{array}{c}\mathrm{N}^{\circ} \text { of } \\
\text { citations }\end{array}$ \\
\hline \hline Journal of Air Transport Management & 370 \\
\hline $\begin{array}{l}\text { Transportation Research Part A Policy and } \\
\text { Practice }\end{array}$ & 163 \\
\hline $\begin{array}{l}\text { Transportation Research Part E Logistics and } \\
\text { Transp. Review }\end{array}$ & 130 \\
\hline Transport Policy & 83 \\
\hline $\begin{array}{l}\text { Physica A: Statistical Mechanics and Its } \\
\text { Applications }\end{array}$ & 48 \\
\hline Journal of Transport Geography & 44 \\
\hline $\begin{array}{l}\text { Transportation Research Part B } \\
\text { Methodological }\end{array}$ & 43 \\
\hline Sustainability & 40 \\
\hline Journal of Cleaner Production & 37 \\
\hline European Journal of Operational Research & 35 \\
\hline
\end{tabular}

www.vosviewer.com/download/), in which it is evident that if one term is represented next to another, both are associated under some relationship criteria.

In the author co-citation map (Figure 2), each node represents a different researcher and the size of the node reflects the volume of the authors' citations. The map groups the authors in "clusters" of random colours indicating different trends of knowledge on the analysed topic [36]. The threshold for the co-citation analysis was set at 10 author co-citations, and 


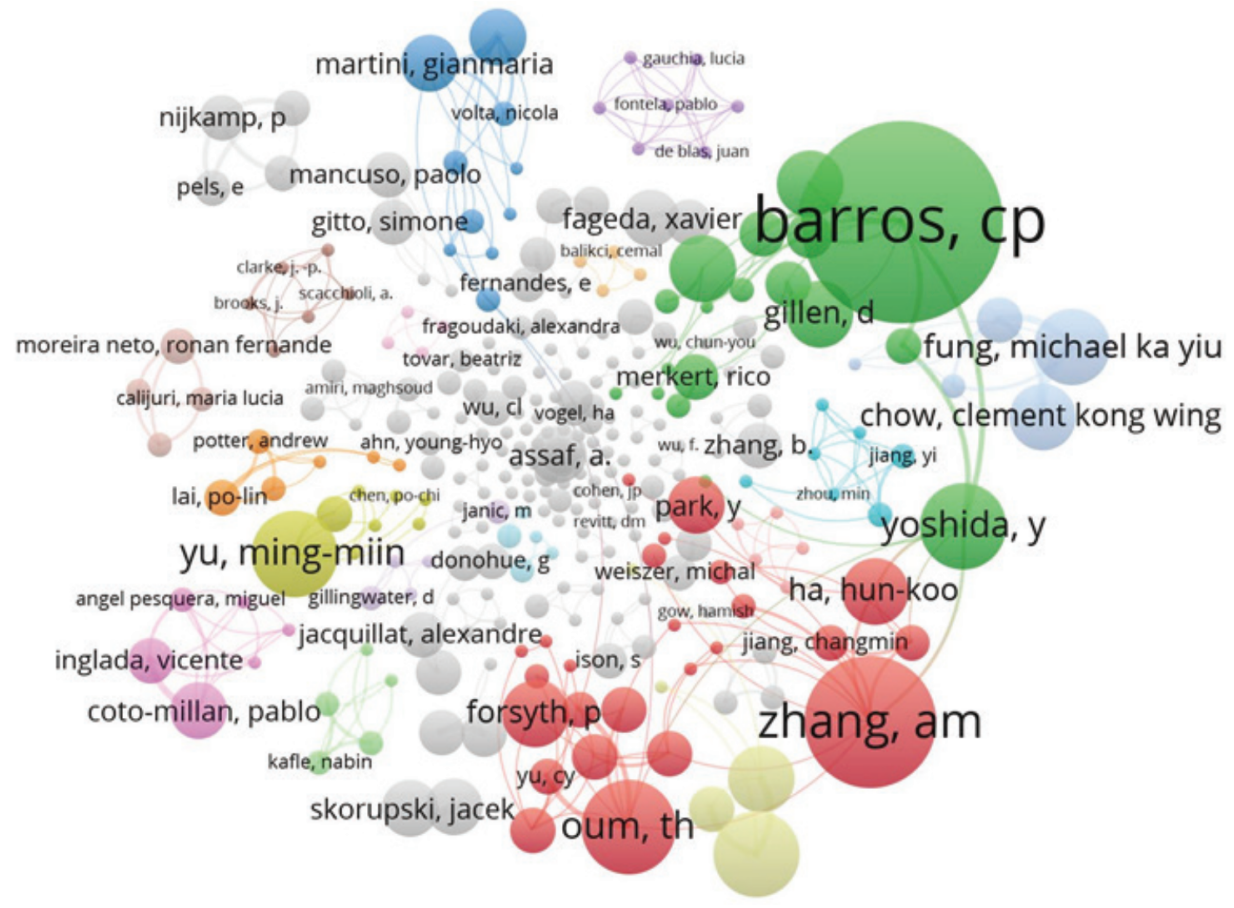

Figure 2-Map of co-citations by author (WoS, 2000-2019)

the one led by Barros stands out among the groups formed. Gillen and Yoshida, among others, also belong to this group, which is characterised by the study of efficiency by applying the DEA method. Another group that stands out is formed by Zhang and other researchers such as Oum, who focus on economic issues related to airport charges, privatisation, and concession income.

The analysis of co-words complements the analysis of co-citation by adding thematic specificity to the previous analysis. This measures documentary similarity by detecting the terms that appear according to their degree of co-occurrence. The most commonly used terms have been determined from the analysis of the title and the abstract. VOSviewer counted 11,942 terms, of which 341 appear at least 10 times and 139 at least 20 times. To leave less important terms out of the map, the relevance score has been calculated for the 139 terms and the most relevant terms have been selected from these. Three groups were formed: red, which focuses on aspects of security, structure, and management of the airport, with the key terms "service", "terminal", "aircraft", "delay", or "runway"; green, which is related to efficiency by applying parametric and non-parametric boundaries (DEA), with the key terms such as "productivity", "technical efficiency", "airport efficiency", and "output"; and finally, blue, which refers to the issue of airport regularization, with the key terms "government", "regulation", "ownership", or "privatization".

Although not reflected in Figure 3, the environmental aspect related to airports has been gaining in importance. In the analysed database, there are 81 works interrelated with sustainability and almost $70 \%$ of them have been published in the last 5 years. There is great concern about optimising airport surface operations and scheduling runways, as more and more airports are facing serious congestion and stricter environmental regulations. In addition, consideration is being given to how to reduce $\mathrm{CO}_{2}$ emissions. These publications are more frequent in the journals Sustainability, Journal of Air Transport Management, and Transportation Research Part D-Transport and Environment. The author with the largest number of publications is Gianmaria Martini, with 5 articles. One of his articles, The Influence of Fleet Mix, Ownership and LCCS on Airports' Technical/Environmental Efficiency, also signed by Alessandro Manello and Davide Scotti, and published in Transportation Research Part E-Logistics and Transportation Review in 2013, has 41 citations. Also noteworthy is the work of Kilkis and Kilkis, Benchmarking Airports Based on a Sustainability Ranking Index, published in the Journal of Cleaner Production in 2016, which has more than 


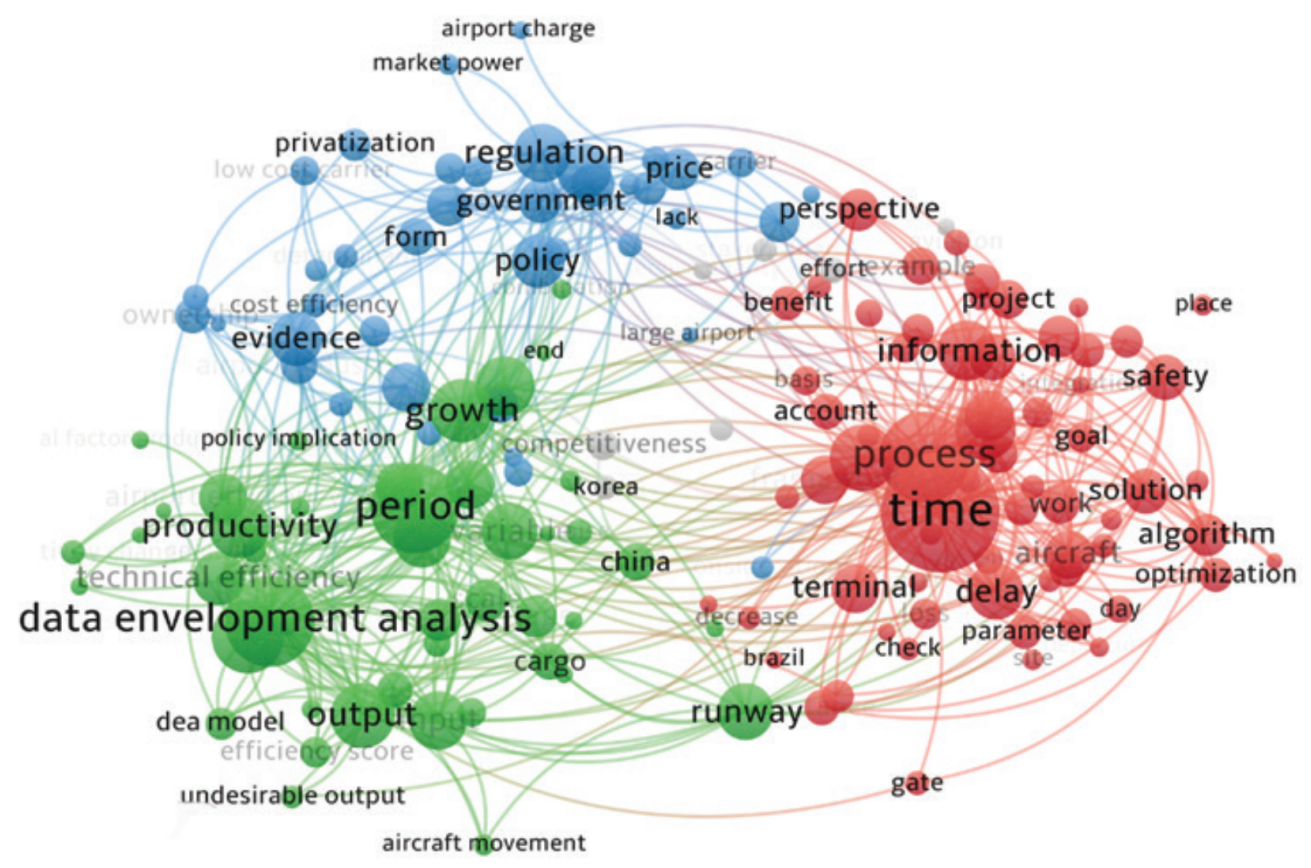

Figure 3-Most used terms in research on airport efficiency (WoS, 2000-2019)

30 citations. In general, the number of citations is low, because these are articles published in the recent years.

\section{DISCUSSION}

An exploratory-descriptive study with a retrospective design of the papers published in WoS was carried out by means of a bibliometric analysis of papers along the lines of research related to airport efficiency. Inclusion criteria were established for articles published in the last 20 years.

Interest in the subject has increased during the study period, as evidenced by the growing number of publications and the increase in the number of productive authors. We identified 671 articles in the field in 262 journals indexed in the WoS.

Several traditional transport journals, including the Journal of Air Transport Management, Transportation Research Part E-Logistics and Transportation Review and Transportation Research Part A-Policy and Practice, are the most widely used for publications, while the journal Sustainability has been identified as the first choice for articles on airport efficiency that is not transport-specific. One of the topics that has received the most attention in recent years is that related to environmental aspects.

Optimization techniques are mainly used, and the ones most frequently used are data envelopment analysis and stochastic boundaries. The most cited authors in the WoS are Barros, CP and Oum, T.H. In addition, the Journal of Air Transport Management is the one that has the largest number of cited articles and publications.

When identifying the topics most related to the study of efficiency, the areas of transport and engineering stand out above the rest. Words such as "Data Envelopment Analysis", "Time", "Analysis", and "Productivity" have a bearing on the study of airport efficiency. There are three general lines of research. One related to aspects of airport safety, structure and management ("service", "terminal", "aircraft", "delay", "runway", ...); another related to efficiency by applying parametric and non-parametric frontiers (DEA), and another concerning airport regularization issues ("government", "regulation", “ownership", "privatization”...).

\section{CONCLUSION}

The rapid progression of scientific knowledge with an increasing number of publications requires reviews of the scientific literature in order to have up-to-date knowledge on a subject. This is also the case in the field of airport efficiency research. This is an emerging topic that has received a lot of attention in various fields, as shown by the increase in the number of authors, articles, and diversity of journals. The interest is recent, as the largest production is seen from 2013 onwards. 
This study reflects the growing trend in research on airport efficiency, evidenced by a large increase in work in this area in recent years. The advances in the different techniques for measuring efficiency are being reflected in the recent papers published on this subject. This work will allow researchers to search more quickly for publications related to efficiency, and they can go directly to the journal or consult researchers who specialise in this area.

Although it is possible to know the state of current research on the subject of airport efficiency thanks to this review, it is clear that it is not completely exhaustive, as it is only done on the references that exist in the WoS which may be different from those that appear in the Scopus database [13, 35, 37, 38]. Furthermore, it has been found to have errors in identifying authors or institutions, and many of the existing references have errors, both in the nomenclature of the author and in the institution to which the author belongs, which can lead to erroneous conclusions about the productivity of the authors. For this reason, this same study will be carried out by combining various databases since none of them precisely controls all the existing journals $[38,39]$.

CIFUENTES-FAURA, JAVIER, Ph.D. candidate $^{1}$ E-mail: javier.cifuentes@um.es

FAURA-MARTÍNEZ, URSULA, Ph.D. ${ }^{1}$

E-mail: faura@um.es

${ }^{1}$ Universidad de Murcia, Spain

Facultad de Economía y Empresa

Campus de Espinardo, 30100 Murcia, España

\section{VEINTE AÑOS DE EFICIENCIA DE LOS AEROPUERTOS: UN ANÁLISIS BIBLIOMETRICO}

\section{RESUMEN}

En este trabajo se realiza un análisis del estudio cientifico sobre eficiencia de los aeropuertos en la base de datos de WoS (Web of Science) durante el periodo 20002019. Se han obtenido indicadores de productividad por autor, años, revistas e instituciones, junto con un análisis de la visibilidad, impacto y colaboración científica a través de las co-citaciones. Las áreas con mayor aplicación son transporte, ingeniería y economía. Este estudio revela la existencia de tres lineas de investigación, una sobre seguridad y gestión de los aeropuertos, otra sobre la eficiencia técnica empleando principalmente el método DEA, y una tercera asociada con cuestiones de regularización de los aeropuertos. Se constata el aumento de trabajos sobre cuestiones medioambientales. En el ranking de revistas que publican sobre eficiencia aeroportuaria, ordenadas por el número de artículos indexados en WoS sobresale Journal of Air Transport Management, mientras que Sustainability destaca como la primera revista no especifica sobre transporte en la que se realizan publicaciones sobre eficiencia de los aeropuertos. Los investigadores de la Universidad de Lisboa y de la Universidad de British Columbia son los que más tratan esta temática.

\section{PALABRAS CLAVE}

Análisis bibliométrico; eficiencia, aeropuertos; Web of Science; co-citaciones.

\section{REFERENCES}

[1] Jarach D. Airport marketing. Strategies to cope with the new millennium environment. Hampshire: Ashgate Publishing Limited; 2005.

[2] Awiti AO, et al. Effect of airport expansion on business opportunities in Kisumu. International Journal of Business and Behavioral Sciences. 2013;3(2): 1-5.

[3] Alamá-Sabater L, Artal-Tur A, López Olivares D. Air transport and tourism: An study for the Spanish Mediterranean region. Investigaciones Regionales. 2019;43: 149-164.

[4] Ishutkina MA, Hansman RJ. Analysis of the interaction between air transportation and economic activity: $A$ worldwide perspective. MIT International Center for Air Transportation. Report No. ICAT-2009-2, 2009.

[5] Chi J, Baek J. Dynamic relationship between air transport demand and economic growth in the United States: A new look. Transport Policy. 2013;29: 257-260. DOI: 10.1016/j.tranpol.2013.03.005

[6] Silling U. Aviation of the Future: What needs to change to get aviation fit for the twenty-first century. In: Sikander A. (ed.) Aviation and Its Management-Global Challenges and Opportunities; 2019. DOI: 10.5772/intechopen. 81660

[7] Carbonell X, Calvó N. Las revistas españolas de psicología: cómo elegir la revista donde publicar [Spanish psychology journals: How to choose the journal to publish in]. Anales de Psicología. 2009;25(2): 209-216.

[8] Osca-Lluch J, Civera-Mollá C, Peñaranda-Ortega M. Consecuencias de los errores en las referencias bibliográficas. El caso de la revista Psicothema [Consequences of errors in bibliographic references. The case of the journal Psicothema]. Psicothema. 2009;21: 300-303.

[9] Zych I, Buela-Casal G. Internacionalidad de las revistas de psicología multidisciplinar editadas en Iberoamérica e incluidas en la Web of Science [Internationality of multidisciplinary psychology journals published in Iberoamerica and included in the Web of Science]. Universitas Psychologica. 2010;9(1): 27-34. DOI:10.11144/Javeriana. upsy9-1.irpm

[10] Navarrete-Cortés J, et al. Análisis cuantitativo por países de la productividad en psicología de las revistas en la Web of Science [Quantitative analysis by country of the productivity in psychology of journals in the Web of Science]. Revista Mexicana de Psicología. 2009;26(2): 131-143. 
[11] Falagas ME, Pitsouni EI, Malietzis GA, Pappas G. Comparison of PubMed, Scopus, Web of Science, and Google Scholar: Strengths and weaknesses. The FASEB Journal, Life Sciences Forum. 2008;22: 338-342. DOI: 10.1096/ fj.07-9492LSF

[12] Granda-Orive JI, et al. Ciertas ventajas de Scopus sobre Web of Science en un análisis bibliométrico sobre tabaquismo [Some advantages of Scopus over Web of Science in a bibliometric analysis on smoking]. Revista Española de Documentación Científica. 2013;36(2): e011. DOI: 10.3989/redc.2013.2.941

[13] Bakkalbasi N, Bauer K, Glover J, Wang L. Three options for citation tracking: Google Scholar, Scopus and Web of Science. Biomedical Digital Libraries. 2006;3(7): 1-8. DOI: $10.1186 / 1742-5581-3-7$

[14] Kulkarni AV, Aziz B, Shams I, Busse JW. Comparisons of citations in Web of Science, Scopus, and Google Scholar for articles published in general medical journals. JAMA. 2009;302(10): 1092-1096. DOI:10.1001/ jama.2009.1307

[15] Garfield E. The evolution of the Science Citation Index. International Microbiology. 2007;10: 65-69. DOI: 10.2436/20.1501.01.10

[16] Wang Q, Waltman L. Large-scale analysis of the accuracy of the journal classification systems of Web of Science and Scopus. Journal of Informetrics. 2016;10(2): 347364. DOI: 10.1016/j.joi.2016.02.003

[17] Codina L, Morales-Vargas A, Rodríguez-Martínez R, Pérez-Montoro M. Uso de Scopus y Web of Science para investigar y evaluar en comunicación social: análisis comparativo y caracterización [Use of Scopus and Web of Science for research and evaluation in social communication: Comparative analysis and characterization]. Index.comunicación. 2020;10(3): 235-261. DOI: 10.33732/ ixc/10/03Usodes

[18] González-Zamar MD, Abad-Segura E, Belmonte-Ureña LJ. Aprendizaje significativo en el desarrollo de competencias digitales. Análisis de tendencias [Meaningful learning in the development of digital competencies. Trend analysis]. IJERI: International Journal of Educational Research and Innovation. 2020;14: 91-110. DOI: 10.46661/ijeri.4741

[19] González-Valiente CL. Redes de citación de revistas iberoamericanas de Bibliotecología y Ciencia de la Información en Scopus [Citation networks of Iberoamerican journals of Library and Information Science in Scopus]. Bibliotecas. Anales de Investigación. 2019;19(1): 83-98. DOI: 10.6084/m9.figshare.7415375.v1

[20] De Moya-Anegón F, et al. A new technique for building maps of large scientific domains based on the cocitation of classes and categories. Scientometrics. 2004;61(1): 129-145. DOI: 10.1023/B:SCIE.0000037368.31217.34

[21] Van Eck NJ, Waltman L, Rommert Dekker R, den Berg JV. A comparison of two techniques for bibliometric mapping: Multidimensional scaling and VOS. Journal of the American Society for Information Science and Technology. 2010;61(12): 2405-2416. DOI: 10.1002/ asi. 21421

[22] Van Eck NJ, Waltman L. VOS: A new method for visualizing similarities between objects. In: Decker R, Lenz
HJ. (eds) Advances in Data Analysis. Studies in Classification, Data Analysis, and Knowledge Organization. Springer, Berlin, Heidelberg; 2007. DOI: 10.1007/9783-540-70981-7_34

[23] Van Eck NJ, Waltman L. Software survey: VOSviewer, a computer program for bibliometric mapping. Scientometrics. 2010;84(2): 523-538. DOI:10.1007/s11192-0090146-3

[24] Perianes-Rodriguez A, Waltman L, Van Eck N. Constructing bibliometric networks: A comparison between full and fractional counting. Journal of Informetrics. 2016;10(4): 1178-1195. DOI: 10.1016/j.joi.2016.10.006

[25] Li W, Cai X. Statistical Analysis of Airport Network of China. Physical Review E. 2004;69(4). DOI: 10.1103/ PhysRevE.69.046106

[26] Sarkis J. An analysis of the operational efficiency of major airports in the United States. Journal of Operations Management. 2000;18(3): 335-351. DOI: 10.1016/ S0272-6963(99)00032-7

[27] Sarkis J, Talluri S. Performance based clustering for benchmarking of US airports. Transportation Research Part A: Policy and Practice. 2004;38(5): 329-346. DOI: 10.1016/j.tra.2003.11.001

[28] Martin JC, Roman C. An application of DEA to measure the efficiency of Spanish airports prior to privatization. Journal of Air Transport Management. 2001;7(3): 149157. DOI: $10.1016 / \mathrm{S} 0969-6997(00) 00044-2$

[29] Pels E, Nijkamp P, Rietveld P. Inefficiencies and scale economies of European airport operations. Transportation Research Part E: Logistics and Transportation Review. 2003;39(5): 341-361. DOI: 10.1016/S13665545(03)00016-4

[30] Gillen D, Lall A. Competitive advantage of low-cost carriers: Some implications for airports. Journal of Air Transport Management. 2004;10(1): 41-50. DOI: 10.1016/j.jairtraman.2003.10.009

[31] Oum TH, Yan J, Yu C. Ownership forms matter for airport efficiency: A stochastic frontier investigation of worldwide airports. Journal of Urban Economics. 2008;64(2): 422-435. DOI: 10.1016/j.jue.2008.03.001

[32] Oum TH, Adler N, Yu C. Privatization, corporatization, ownership forms and their effects on the performance of the world's major airports. Journal of Air Transport Management. 2006;12(3): 109-121. DOI: 10.1016/j.jairtraman.2005.11.003

[33] Barros CP, Dieke PU. Performance evaluation of Italian airports: A data envelopment analysis. Journal of Air Transport Management. 2007;13(4): 184-191. DOI: 10.1016/j.jairtraman.2007.03.001

[34] Barros CP, Dieke PU. Measuring the economic efficiency of airports: A Simar-Wilson methodology analysis. Transportation Research Part E: Logistics and Transportation Review. 2008;44(6): 1039-1051. DOI: 10.1016/j.tre.2008.01.001

[35] Bar-Ilan J. Which h-index? - A comparison of WoS, Scopus and Google Scholar. Scientometrics. 2008;74(2): 257-71. DOI: 10.1007/s11192-008-0216-y

[36] Zupic I, Čater T. Bibliometric methods in management and organization. Organizational Research Methods. 2015;8(3): 429-472. DOI: 10.1177/1094428114562629 
[37] López-Illescas C, de Moya-Anegón F, Moed HF. Coverage and citation impact of oncological journals in the Web of Science and Scopus. Journal of Informetrics. 2008;2(4): 304-316. DOI: 10.1016/j.joi.2008.08.001

[38] Delgado López-Cózar E, Repiso-Caballero R. El impacto de las revistas de comunicación: comparando Google Scholar Metrics, Web of Science y Scopus [The impact of communication journals: Comparing Google Scholar Metrics, Web of Science and Scopus]. Comunicar. 2013;21(41): 45-52. DOI: 10.3916/C41-2013-04

[39] Yeung AWK. Comparison between Scopus, Web of Science, PubMed and publishers for mislabelled review papers. Research Communications. 2019;116(11): 1909-1914. DOI: 10.18520/cs/v116/i11/1909-1914 